\title{
Rideshare use among parents and their children
}

\author{
Johnathon P. Ehsani ${ }^{*}$, Jeffrey P. Michael and Andrea Gielen
}

\begin{abstract}
Motor vehicle crashes are the leading cause of death for young children. Millions of ridesharing trips are taken each day, and use of these services is predicted to increase. Therefore, it is important to examine the safety of children in these vehicles. We conducted a survey of a nationally representative sample of U.S. adults aged 18 years or older $(N=2017)$. Of the total sample, 450 respondents reported being a parent or legal guardian of children below the age of 10 . Of these, 307 or $68 \%$ had ever used ridesharing. Among those who had used ridesharing, a total of 253 or $82 \%$ reported using ridesharing with their children below the age of 10 years. Among this group, rideshare use was significantly higher among individuals with college education, and in higher income households. Given that the majority of U.S. states have legislation exempting rideshare vehicles from child restraint system law coverage, our finding of high rates of rideshare use among parents suggests that a large number of children could be at risk of injury due to a lack of appropriate restraint use.
\end{abstract}

\section{Introduction}

Prior to the COVID-19 pandemic, ridesharing companies such as Lyft and Uber provided over 4 million trips per day in urban and suburban areas (Uber Technologies Inc, 2019). In 2019, Uber released a safety report indicating that the fatal crash risk of their trips is comparable to those among adults using personal vehicles who are likely to be traveling with young children (Uber Technologies Inc, 2019; Tefft, 2017). While considerable advances have been made in child restraint use in personal vehicles (Li \& Pickrell, 2018), motor vehicle crashes remain the leading cause of death for young children (Centers for Disease Control and Prevention, 2020) and the lack of restraint use has been identified as a key risk factor in fatal crashes involving children (Wolf et al., 2017). As rideshare use is predicted to increase in coming years, it is important to determine the prevalence ridesharing use among families with children.

\footnotetext{
* Correspondence: johnathon.ehsani@jhu.edu

Center for Injury Research and Policy, Department of Health Policy and Management, Johns Hopkins Bloomberg School of Public Health, $624 \mathrm{~N}$. Broadway, Hampton House 555, Baltimore, MD 21205, USA
}

\begin{abstract}
Methods
We conducted an online survey of a nationally representative sample of U.S. adults aged 18 years or older between December 12th and 16th, 2019. We used the general population sample $(N=2017)$ to identify our sample of interest, i.e. parents/legal guardians of children below age $10(N=450)$. Parents/legal guardians were asked if they have ever used rideshare (e.g., Uber, Lyft, etc.) and if yes, if their children below the age of 10 have ever been in a ride share with them. Respondents were not asked about the use of child restraints in ridesharing.

Participants were recruited from The Harris Poll optin panel. This is not a probability-based sample, which means an estimate of sampling error cannot be calculated. Demographic and propensity score statistical weighting were applied to adjust for respondents' propensity to be online and to ensure the results are representative of the general population. The Johns Hopkins Bloomberg School of Public Health institutional review board deemed this study not human participants research.
\end{abstract}

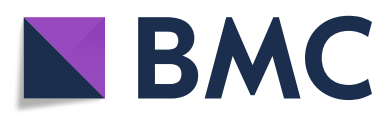

C The Author(s). 2021 Open Access This article is licensed under a Creative Commons Attribution 4.0 International License, which permits use, sharing, adaptation, distribution and reproduction in any medium or format, as long as you give appropriate credit to the original author(s) and the source, provide a link to the Creative Commons licence, and indicate if changes were made. The images or other third party material in this article are included in the article's Creative Commons licence, unless indicated otherwise in a credit line to the material. If material is not included in the article's Creative Commons licence and your intended use is not permitted by statutory regulation or exceeds the permitted use, you will need to obtain permission directly from the copyright holder. To view a copy of this licence, visit http://creativecommons.org/licenses/by/4.0/. The Creative Commons Public Domain Dedication waiver (http://creativecommons.org/publicdomain/zero/1.0/) applies to the data made available in this article, unless otherwise stated in a credit line to the data. 


\section{Results}

From the sampling frame of 2017 U.S. adults, a total of 450 respondents reported being a parent or legal guardian of children below the age of 10 . Of these, 307 or $68 \%$ had ever used ridesharing. Among those who had used ridesharing, a total of 253 or $82 \%$ reported using ridesharing with their children below the age of $10 \mathrm{y}$. Rideshare use with children was significantly higher among individuals with some college education compared to those with high school education or less (57\% compared to $47 \%$ ), and in households with an income of $\$ 50,000$ or higher compared to those below $\$ 50,000$ (60\% compared to $43 \%$ ). Adults between 18 and 34 years and those 35-44 years reported the highest percentage of ridesharing use (71 and 65\% respectively), and these groups were also the most likely to report having children ages 9 or under (38 and $47 \%$ respectively).

\section{Discussion}

At the time of this survey, 34 U.S. states have legislation exempting rideshare vehicles from child restraint system (CRS) law coverage (Owens, 2019). Our finding of high rates of rideshare use among parents suggests that a large number of children could be at risk of injury due to a lack of appropriate restraint use. Consistent with prior studies, rideshare use was higher among more educated and affluent segments of the population (Jiang, 2019). While we did not assess the actual use of CRS in rideshare vehicles, previous research indicates that nearly $60 \%$ of parents/caregivers reported transporting children under 5 years of age differently in rideshare than in a personal vehicle, with $37 \%$ reporting holding children on their lap and 25\% letting a child ride without an appropriate child seat (Owens, 2019). CRS use rates in taxi's also provide an indication of CRS use rates in for-hire vehicles. Using crash data from New York City, Prince and colleagues found that CRS use was less than $6 \%$ in taxis involved in a crash in which a child was injured (Prince et al., 2019).

While challenges remain, CRS use in personal vehicles has largely been a public health success. Observational surveys indicate that in 2017, passenger vehicle CRS use was $97.9 \%$ among children < 1 year of age, $95.3 \%$ among children 1-4 years of age, $89.4 \%$ among children $4-7$ years, and $84.4 \%$.among children $8-12$ years (Li \& Pickrell, 2018). We expect use rates to be lower in ridesharing trips because of the widespread practice of exempting these vehicles in state laws, and because of the difficulties parents can face in using CRS in ridesharing vehicles. Notably, ordering a rideshare that includes a company-provided CRS can substantially increase the cost of a trip. This may become an additional barrier to their adoption and use.
Pediatricians and injury prevention practitioners can reinforce the need for appropriate CRS use when using any vehicle, including those for hire, such as rideshare and taxis. Companies could demonstrate their commitment to safety by requiring CRS use regardless of the state law and providing a CRS when needed. As personal vehicle ownership declines and trips are increasingly likely to take place in ridesharing vehicles and taxis (Polzin et al., 2014), engineering solutions will be needed to provide CRS options that are easily carried and stored, or even built into vehicles. Such added convenience could encourage parents, caregivers and drivers to ensure child passenger safety in rideshare vehicles. In the longer term, a coordinated strategy is needed to address gaps in state legislation regarding CRS use in ridesharing vehicles.

This study is based on responses from the Harris Online panel, which is a non-probability sample. This means the results may be vulnerable to sampling biases such as self-selection. To adjust the sample to be nationally representative, a propensity weight was applied to each individual respondent's data. However, it is possible that some bias remained in the sample, even after the weights were applied (Copas et al., 2020). This may be one reason why the prevalence of ridesharing in our study was marginally higher than what was reported in other surveys (Jiang, 2019).

CRS use reduces risk of serious injury or death for children in a crash (Arbogast et al., 2004). There is an urgent need for action to ensure that use of rideshare does not increase child injury risk. The first step is to determine accurate estimates of CRS use in rideshare vehicles, which is currently unknown, and identify barriers and facilitators of CRS use in such vehicles. Progress in personal mobility in the U.S. should not be accompanied by setbacks in child safety.

\section{Abbreviation \\ CRS: Child restraint systems}

\section{Acknowledgements}

Not applicable

\section{Authors' contributions}

Dr. Ehsani conceptualized and designed the study, designed the data collection instruments, and carried out the analyses. Dr. Michael conceptualized and designed the study and reviewed and revised the manuscript. Dr. Gielen critically reviewed the manuscript for important intellectual content. The authors read and approved the final manuscript.

\section{Funding}

This research was not supported by any funding sources

Financial disclosure

The authors have no financial relationships relevant to this article to disclose.

Ethics approval and consent to participate Not applicable. 


\section{Consent for publication}

Not applicable.

\section{Competing interest}

The authors have no conflicts of interest relevant to this article to disclose.

Received: 5 November 2020 Accepted: 30 January 2021

Published online: 01 March 2021

\section{References}

Arbogast KB, Durbin DR, Cornejo RA, Kallan MJ, Winston FK. An evaluation of the effectiveness of forward facing child restraint systems. Accid Anal Prev. 2004; 36(4):585-9.

Centers for Disease Control and Prevention. WISQARS Leading Cause of Death Reports, 1999-2017. 2020.

Copas A, Burkill S, Conrad F, Couper MP, Erens B. An evaluation of whether propensity score adjustment can remove the self-selection bias inherent to web panel surveys addressing sensitive health behaviours. BMC Med Res Methodol. 2020;20(1):251.

Jiang J. More Americans are using ride-hailing apps [Internet], 2019. Pew Research Center. [viewed 2021 Jan 4]. Available from: https://www.pewresea rch.org/fact-tank/2019/01/04/more-americans-are-using-ride-hailing-apps/

Li HR, Pickrell T, 2018 The 2017 National Survey of the Use of Booster Seats (Report No. DOT HS 812 617). Washington, DC: Nationals Highway Traffic Safety Administration. Washington: National Highway Traffic Safety Administration; Report No: DOT HS 812617.

Owens J. Factors surrounding child seat usage in rideshare services [internet]. 2019 Available from: https://www.vtti.vt.edu/utc/safe-d/wp-content/uploa ds/2019/10/01-005_FinalResearchReport_Final.pdf

Polzin SE, Chu X, Godfrey J. The impact of millennials' travel behavior on future personal vehicle travel. Energy Strat Rev. 2014;5:59-65.

Prince P, Hines LM, Bauer MJ, Liu C, Luo J, Garnett M, et al. Pediatric restraint use and injury in New York City taxis compared with other passenger vehicles. Transp Res Rec. 2019:0361198119843091.

Tefft B. Rates of Motor Vehicle Crashes, Injuries and Deaths in Relation to Driver Age, United States, 2014-2015. AAA Foundation for Traffic Safety 2017;

Uber Technologies Inc. Uber Safety Report 2017-2018 [Internet]. Uber. [cited 2019 Dec 31]. Available from: https:/www.uber.com/us/en/about/reports/ussafety-report

Wolf LL, Chowdhury R, Tweed J, Vinson L, Losina E, Haider AH, et al. Factors Associated with Pediatric Mortality from Motor Vehicle Crashes in the United States: A State-Based Analysis. J Pediatr. 2017; 187: 295-302.e3.

\section{Publisher's Note}

Springer Nature remains neutral with regard to jurisdictional claims in published maps and institutional affiliations.

Ready to submit your research? Choose BMC and benefit from:

- fast, convenient online submission

- thorough peer review by experienced researchers in your field

- rapid publication on acceptance

- support for research data, including large and complex data types

- gold Open Access which fosters wider collaboration and increased citations

- maximum visibility for your research: over $100 \mathrm{M}$ website views per year

At BMC, research is always in progress.

Learn more biomedcentral.com/submissions 